\title{
Experimental tests on winter cereal: Sod seeding compared to minimum tillage and traditional plowing
}

\author{
Antoniotto Guidobono Cavalchini, ${ }^{1}$ Gian Luca Rognoni, ${ }^{2}$ Francesco M. Tangorra, ${ }^{1}$ \\ Annamaria Costa ${ }^{1}$ \\ 'Department of Health, Animal Science and Food Safety, Università degli Studi di Milano, Milano, \\ Italy; ${ }^{2}$ Agronomist
}

\begin{abstract}
Compared to traditional plowing and minimum tillage, the sod seeding technique has been tested in order to evaluate the differences in energy consumption, labor and machinery requirement and $\mathrm{CO}_{2}$ emission reduction. The experiments were conducted on winter cereal seeding in a Po valley farm in 0ctober 2011. The tests were carried out as follows: wheat variety seeding, over corn and alfalfa crops, in large plots with three repetitions for each thesis. They included: sod seeding anticipated by round up weeding in the case of the plots over alfalfa; traditional plowing at $35 \mathrm{~cm}$ followed by rotary tillage and combined seeding (seeder plus rotary tiller); minimum tillage based on ripping at the same depth $(35 \mathrm{~cm})$ and combined seeder ( seeder plus rotary tiller). The following farm operations - fertilizer, and other agrochemical distributionshave been the same in all the considered theses. The results, statistically significant $(\mathrm{P}<0.001)$ in terms of yields, highlighted slight differences: the best data in the case of the traditional plowing both in the case of wheat crop over corn and alfalfa ( 84.43 and $6.75 \mathrm{t} / \mathrm{ha}$ ); slightly lower yields for the sod seeding (6.23 and 79.9 t/ha for corn and alfalfa respectively); lower in the case of minimum tillage (5.87; $79.77 \mathrm{t} / \mathrm{ha}$ in the two situations). Huge differences in energy and oil consumption have been recorded: in the case of succession to corn $61.47 ; 35.31 ; 4.27$ $\mathrm{kg}$ oil/ha respectively for, traditional plowing, minimum tillage and sod seeding; in the case of alfalfa $61.2 ; 50.96 ; 5.14 \mathrm{~kg}$ oil/ha respectively for traditional plowing, minimum tillage and sod seeding. The innovative technique, highlighted huge energy saving with an oil consumption equal to $92 \%$ and $89 \%(P<0.001)$ of what happens in traditional plowing and minimum tillage. Large differences concern labor and machine productivity. These parameters together with oil consumption and machine size [power $(\mathrm{kW})$ and weight $(\mathrm{t})$ ] lead to even greater differences in terms of energy consumption, efficiency and $\mathrm{CO}_{2}$ emission savings.
\end{abstract}

Correspondence: Antoniotto Guidobono Cavalchini, Department of Health, Animal Science and Food Safety, Università degli Studi di Milano, Via Celoria 10, 20133, Milano, Italy.

E-mail: antoniotto.cavalchini@unimi.it

Key words: cropping system, sod seeding, energetic balance, $\mathrm{CO}_{2}$ emissions.

(C) Copyright A. Guidobono Cavalchinil et al., 2013

Licensee PAGEPress, Italy

Journal of Agricultural Engineering 2013; XLIV(s2):e79

doi:10.4081/jae.2013.s2.e79

This article is distributed under the terms of the Creative Commons Attribution Noncommercial License (by-nc 3.0) which permits any noncommercial use, distribution, and reproduction in any medium, provided the original author(s) and source are credited.
Considerations related to the different mechanizations chains, investments required and to some new practices to be introduced, such as low pressure tires or crawlers, ideal lanes, GPS and automatic guide systems to follow the ideal lanes, conclude the study.

\section{Introduction}

The first proposals and tests on sod seeding cropping systems date back to the 1940s in England, but only the arrival on the market of Gramoxone (Syngenta,Switzerland), a non-selective herbicide, allowed the follow up and development of trials to study the tillage system. The development of this technique, dates back to the end of the $70 \mathrm{~s}$ in South America (Argentina and Brazil), and North America (USA). Currently sod seeding is practiced on about 110 million hectares, mainly in South America. No wonder sod seeding tillage machine manufacturers are mostly Argentine and Brazilian. However, in the last decades many models have been produced by Italian and European manufacturers.

In Italy, sod seeding is a cropping system in development, especially practiced in central Italy, but it is also moderately used in certain flat areas as the Pianura Padana. Thanks to the interest shown by researchers and associations whose aim is the development of the tillage system. In fact, some Italian regions provide funding to anyone who uses this technique for at least 5 years.

The standard cropping method in Italy (conventional tillage, CT), with slight modifications depending on crop and type of soil, includes mouldboard ploughing to a depth of $30-40 \mathrm{~cm}$, field cultivation, one or more harrowing passages and sowing. Reduced tillage methods allows energy savings of between 32 and 57\% in corn (Cantele and Zanin, 1983), and greater savings can be achieved by no-tillage (Sartori and Peruzzi, 1994; Tebriigge et al., 1994).

It is worthwhile to study alternative soil tillage methods. In Italy, on average, they account for around a third of the energy input (Bonari $e t$ $a l ., 1992)$. They also influence other production factors (Toderi and Bonari, 1986), which in turn contribute to total energy costs in different ways.

The purpose of this study, therefore, wishes to compare three cropping systems (sod seeding $v s$. minimum tillage and conventional plowing) in a flat area of Northern Italy characterized by clay soils, focusing on aspects of energy such as fuel consumption per unit area, energy efficiency, reduction of emissions and implications on agricultural mechanization. The aim of this research is also the definition and design of machines specifically made for hilly farming. Machinery produced in South or North America, is not suitable for marginal hill mountain areas. While in the flat areas, the benefits are basically energetic and economic; in hilly farming sod seeding also ensures a substantial reduction in soil erosion and instability, usually induced by conventional techniques. 


\section{Materials and methods}

The tests were carried out in the 2011-2012 period in the Oltrepò Pavese plains, an area characterized by silt-clay soils (Table 1), while other preliminary tests took place in the Appennino Ligure Piemontese, $750 \mathrm{~m}$ above sea level (Borgo Adorno, Cantalupo Ligure, AL).

While in the latter, the purpose of the tests was to check the operability of the machines, in the former a strict protocol was followed in order to obtain reliable results.

Thus, two sets of large lots (around 0.5-1 ha) were considered. The first over corn, the second over alfalfa (at end of cycle, $V$ year).

In both cases, the same variety of wheat was sowed (Asuncion by APSOV).

The sod seeding system was compared to other two techniques:

- conventional plowing at $35 \mathrm{~cm}$ depth, followed by secondary preparation of the soil by rotary harrow (10 $\mathrm{cm}$ deep) and seeding with combined machinery (drill coupled to rotary harrow);

- reduced tillage by ripper (35 $\mathrm{cm}$ depth), followed by seeding with drill coupled to rotary harrow.

For each thesis three repetitions were carried out. The rectangular, contiguous parcels were chosen in order to avoid discontinuities and interference due to the headland and drainage channels.

Plowing and subsoiling depth was intentionally limited to $35 \mathrm{~cm}$, while the local practice is $40-45 \mathrm{~cm}$ : this was done so as not to penalize conventional techniques and because depths greater than $35 \mathrm{~cm}$ in tillage are not justified.

A $75 \mathrm{~kW}$ tractor (Fendt 311, AGC0 Corporation, Germany) was used on sod seeding parcels, while $150 \mathrm{~kW}$ tractor power (John Deere 7530, John Deere, USA ) was used on the other two parcels.

Machine features are shown in Table 1.

The investment in seeds was $400 \mathrm{seeds} / \mathrm{m}^{2}$, about $170 \mathrm{~kg} / \mathrm{ha}$ in all the compared theses. Only the sod seeding over alfalfa required additional weed control with glyphosate $(0.9 \mathrm{~kg} / \mathrm{ha})$ ten days before drilling. All other operations as fertilizing, post emergency weeding and phytosanitary treatments were carried out in the same manner in all theses.

The following data were recorded:

- speed and work efficiency of the single operations;

- fuel consumption, using a completely full and subsequent refilling of the tank after working in each parcel;

- $\quad$ slips via speed measurement;

- yields, by weighing the harvested product.

Figure 1 shows the climatic data of the period (October 2011-July 2012); it also shows the dates of the cultural practices.

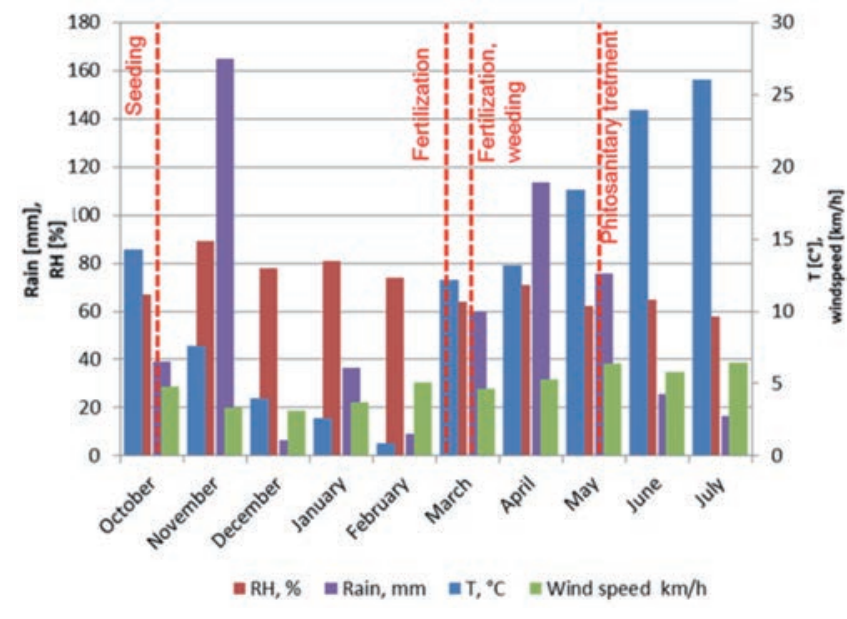

Figure 1. Climatic data, wind speed and rain intensity during the trial.

Table 1. Description of the trials.

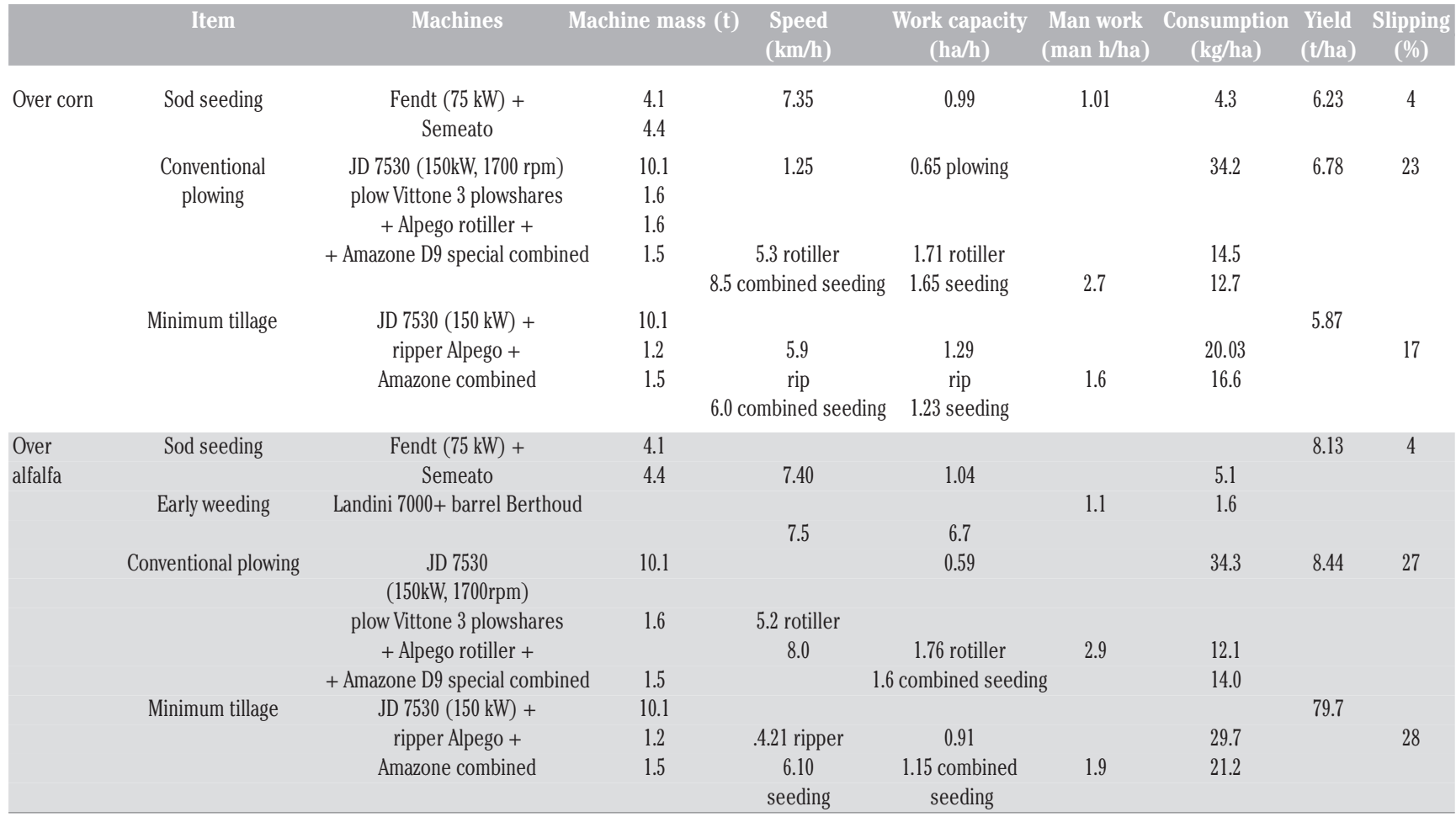


On the basis of recorded data, machine mass and agrochemicals used (Tables 1,2 and 3 ), energy and $\mathrm{CO}_{2}$ emissions analyses were subsequently carried out according to established methodologies.

\section{Results}

\section{Production}

As summarized in Table 4, in both trials (over corn and over alfalfa), the production obtained from the sod seeding cropping system was lower than that obtained with the traditional tillage, but higher than with the minimum tillage technique.

The results are very satisfactory although the conclusions can be drawn only after a number of years. Moreover, the sod seeding technique maximizes the benefits after at least 5 years, during which the crop residues (straw, stalks, etc.) are left on the ground in order to increase surface organic substance resulting in significant advantages.

\section{Capacity and productivity}

\section{Sod seeding}

- Weeding is only necessary in cases of seeding on lawn, in our case over alfalfa. With a working width of $15 \mathrm{~m}$ and a speed of $7.3 \mathrm{~km} / \mathrm{h}$ the actual working capacity was $6.7 \mathrm{ha} / \mathrm{h}$;

- Seeding: the speed recorded in the two trials (over corn and over alfalfa) was the same, while the work efficiency was slightly higher for the trial over alfalfa: $1,04 \mathrm{ha} / \mathrm{h}$ compared to $0.99 \mathrm{ha} / \mathrm{h}$ (over corn). This was due probably to the sporadic blockage of the machine with crop residues (Figure 2). In both situations, however, the ability to work effectively deviates significantly from the theoretical one. This is due to drill size used on sod seeding, of drawn

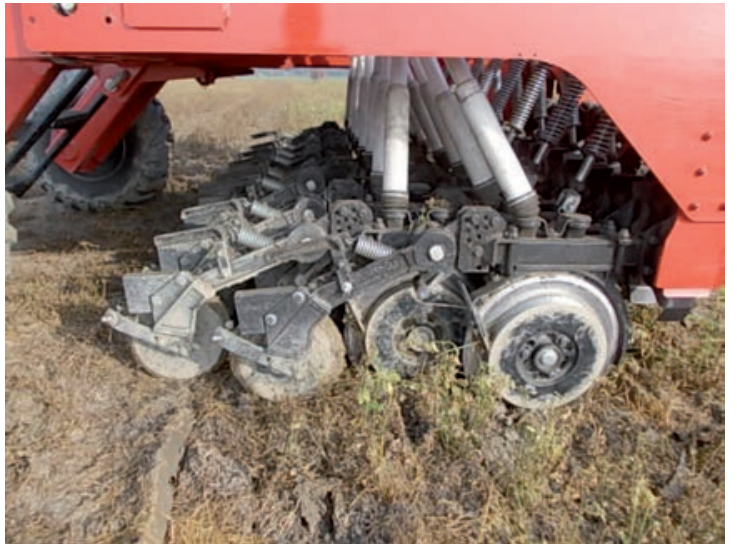

Figure 2. Seeding on alfalfa residues.

Table 2. Agrochemicals used in the trials.

\begin{tabular}{|c|c|c|c|c|}
\hline Intervention & Time & $\begin{array}{c}\text { Fertilizer/ } \\
\text { substance used }\end{array}$ & $\begin{array}{l}\text { Amount distributed } \\
\text { (kg /ha) }\end{array}$ & $\begin{array}{l}\text { Energetic costs } \\
\text { (MJ/ha, kep/ha ) }\end{array}$ \\
\hline $\begin{array}{l}\text { Preventive weed } \\
\text { (only sod seeding over alfalfa) }\end{array}$ & October, $2, .2011$ & Glyphosate & 0.92 & $2.3 \mathrm{kep} / \mathrm{ha}$ \\
\hline Fertilization & March, 10, 2012 & Ammonium nitrate $33.5 \%$ & $\begin{array}{l}\text { Theses over alfalfa } 54 \mathrm{kgN} / \mathrm{ha} \\
\text { Theses over corn } 50 \mathrm{kgN} / \mathrm{ha}\end{array}$ & $\begin{array}{l}99.36 \mathrm{kep} / \mathrm{ha} \\
92 \mathrm{kep} / \mathrm{ha}\end{array}$ \\
\hline Weed & March 29, 2012 & $\begin{array}{c}\text { Ioxinil-otanoato } \\
\text { +bromoxinil+sorbitan monooleato etossilato }\end{array}$ & 0.86 & $2.15 \mathrm{kep} / \mathrm{ha}$ \\
\hline Fertilization & March, 10, 2012 & Ammonium nitrate $33.5 \%$ & $\begin{array}{l}\text { Theses over alfalfa } 47 \mathrm{kgN} / \mathrm{ha} \\
\text { Theses over corn } 110 \mathrm{kgN} / \mathrm{ha}\end{array}$ & $\begin{array}{l}86.5 \mathrm{kep} / \mathrm{ha} \\
184 \mathrm{kep} / \mathrm{ha}\end{array}$ \\
\hline Phytosanitary treatment & May 132012 & Tebuconazole+ deltamethrin & 0.23 & $0.575 \mathrm{kep} / \mathrm{ha}$ \\
\hline
\end{tabular}

Energy equivalents used are shown in Table 3.

Table 3. Energetic equivalents adopted.

\begin{tabular}{|c|c|c|c|}
\hline Machines, agrochemicals & & \multicolumn{2}{|c|}{ Equivalent } \\
\hline Trucks, $7500 \mathrm{~h}$ of life & & 11.5(MJ/t.h) & $0.27 * 10-3$ tep/t.h \\
\hline Plow, reaper, $5000 \mathrm{~h}$ of life & & $8.6(\mathrm{MJ} / \mathrm{t} . \mathrm{h})$ & $0.20 * 10-3$ tep/t.h \\
\hline Seeders, sprayers, manure spreaders, $5000 \mathrm{~h}$ of life & & 17.3(MJ/t.h) & $0.41 * 10-3$ tep/t.h \\
\hline Fertilizers & $\begin{array}{l}(\mathrm{N}) \\
\left(\mathrm{K}_{2} \mathrm{O}\right) \\
\left(\mathrm{P}_{2} \mathrm{O}_{5}\right)\end{array}$ & $\begin{array}{c}77(\mathrm{GJ} / \mathrm{t}) \\
14.6(\mathrm{GJ} / \mathrm{t}) \\
9.7(\mathrm{GJ} / \mathrm{t})\end{array}$ & $\begin{array}{l}1.84(\text { tep/t) } \\
0.35(\text { tep/t) } \\
0.23(\text { tep/t) }\end{array}$ \\
\hline Phytosanitary products & & $105(\mathrm{GJ} / \mathrm{t})$ & $2.50($ tep/t) \\
\hline Fuel & & $46(\mathrm{GJ} / \mathrm{t})$ & $1.1($ tep/t) \\
\hline Oil & & $84(\mathrm{GJ} / \mathrm{t})$ & $2.0(\mathrm{tep} / \mathrm{t})$ \\
\hline Seeds (cereals) & & $21(\mathrm{GJ} / \mathrm{t})$ & $0.5(\mathrm{tep} / \mathrm{t})$ \\
\hline Man work & & $2 \mathrm{MJ} / \mathrm{h}$ uomo & 0.05 (kgep/h man) \\
\hline
\end{tabular}


kind and to the distance between the drawbar and the axis of the machine used that requires a large space or headlands of $20 \mathrm{~m}$.

For sod seeding tillage less than $1 \mathrm{~h}$ man/ha is required over corn and a little more than 1 hour man/ha (1.1 hours man/ha) over alfalfa, which requires a weeding quote.

\section{Traditional plowing}

- Plowing: the working speed showed no significant differences between the operations conducted over corn and alfalfa, with an average value of $5.0 \mathrm{~km} / \mathrm{h}$ which corresponds to a theoretical working capacity of $0.8 \mathrm{ha} / \mathrm{h}$. Work efficiency, higher in the case of parcels cultivated over corn with $0.65 /$ ha $v s$. 0.59 ha/h over alfalfa, may depend on the different sizes of parcels.

- Preparation of the soil with rotary harrow: the working speed detected was $5.3 \mathrm{~km} / \mathrm{h}$, in this case with limited speed differences, while the actual working capacity was $1.7 \mathrm{ha} / \mathrm{h}$;

- Sowing: when performed in combination with rotary harrow at a speed of $8.0 \mathrm{~km} / \mathrm{h}$ showed a work capacity of $1.6 \mathrm{ha} / \mathrm{h}$. For traditional methods, 2.89 hours man/ha were required.

\section{Minimum tillage}

- Subsoiling: in this operation, significantly different values were found between over corn and over alfalfa: $5.9 \mathrm{~km} / \mathrm{h}$ and $1.5 \mathrm{ha} / \mathrm{h}, 4.2$ $\mathrm{km} / \mathrm{h}$ and $0.99 \mathrm{ha} / \mathrm{h}$ over alfalfa respectively. Differences may be due to different soil conditions with particular reference to the precession: 5-year lawn, corn. The value is confirmed by the significantly higher slip and consumption.

- Sowing in combination: the considerations relative to subsoiling can also be applied to cases of sowing carried out with combined machines (rotary harrow and drill). The advancement rate, and the effective work capacity, were substantially the same $-6.0 \mathrm{~km} / \mathrm{h}$ and $1.23 \mathrm{ha} / \mathrm{h}$ for over corn, and $6.10 \mathrm{~km} / \mathrm{h}$ and $1.15 \mathrm{ha} / \mathrm{h}$ for over alfalfa, consumptions were significantly higher in the case of over alfalfa.

1.6 and 1.9 man hours/ha were needed respectively in the case over corn and over alfalfa for minimum tillage.

\section{Fuel consumption}

The results (Table 5) are striking and are confirmed in both situations: succession over corn and alfalfa. For the sod seeding, in the first case, the recorded fuel consumption was $4.27 \mathrm{~kg}$ oil/ha; higher consumption was measured in the trial over alfalfa ( $6.74 \mathrm{~kg} / \mathrm{oil})$ either for its higher tensile forces or for the additional weeding.

On the contrary, conventional methods required the same fuel consumption in both cases: $61.5 \mathrm{~kg} / \mathrm{ha}$ in the former; $61.2 \mathrm{~kg} / \mathrm{ha}$ in the latter, the results are multiples ranging from 8 to 14 times.

Even in the case of minimum tillage, the differences are small: 35.31 and $50.96 \mathrm{~kg} / \mathrm{ha}$ respectively for the succession over corn and alfalfa. Compared to plowing, the savings are considerable, but higher 8 (succession over corn) and 7 times (succession over alfalfa) than for sod seeding.

Consumption and energy waste are further confirmed by the high values of slipping reported in Table $2,25 \%$ for plowing with peaks of $28 \%$ for the subsoiling on alfalfa. In the latter, in fact, consumption was significantly higher than in succession over corn. The slipping recorded in sod seeding tillage was, however, limited to $5 \%$.

\section{Energy balance and emissions}

Evaluations on energy efficiency $\left(\eta=\frac{\text { output }}{\text { input }}\right)$ and emissions of CO2 were carried out on the entire crop cycle, and on the soil tillage operations in order to highlight phase differences, since the other interventions, including agrochemical applications, were the same for all three treatments compared. In fact, energy use in agriculture can be divided into two components: (1) indirect consumption, necessary for production and delivery of farm inputs (fertilizers, pesticides, non-farm feedstuffs, etc.), machinery and equipment, etc.; (2) direct consumption of fuels and electrical energy in the various cropping operations (Cavalchini, 1977, Borin et al., 1997).

As expected, due to lower fuel consumption and machinery requirements, significantly better results were obtained with sod seeding even for the thesis over alfalfa with pre-emergence weed control.

On the other hand, there were no differences in $\eta$ values obtained with conventional methods (plowing) and minimum tillage (ripping).

Traditional plowing was more efficient with regard to thesis over corn, minimum tillage was better in the case of over alfalfa, but it is worth pointing out that this is due to yields that are affected not only by tillage and seeding, but by many other factors. In the case of the entire crop cycle, the differences obviously are less evident, but $\eta$ for sod seeding was always higher (Table 6).

\section{Economic evaluations}

Table 7 shows a summary of costs and incomes of the 3 cropping systems: reported costs are repeatable, those related to incomes are only indicative, since they refer to the specific situation and seasonal trends in which the trial was conducted. The economic benefits coming from the sod seeding when compared to the other two techniques was +230 and $+129 € /$ ha (compared to tillage and minimum tillage) over alfalfa; +79 and $+219 € /$ ha compared to tillage and minimum tillage over corn.

\section{Conclusions}

The tests confirmed sod seeding theories which have been substantiated in agricultural systems worldwide, but still little used in Italy. Energy savings, erosion reduction, conservation of organic substances in relation to production obtained using traditional methods.

On the other hand, the acquired data showed that reduced work techniques resulted in lower production compared to those obtained using either traditional methods or sod seeding, confirming past experience. In spite of this, in the last decades the minimum tillage technique has become quite common, this is due to: increased productivity of machines and operators, intervening swiftly, access of machines and workers to larger areas, lower machine costs.

These factors are the result of sod seeding which are its main

Table 4. Yields obtained in the trial.

\begin{tabular}{lccc} 
Yield & $\begin{array}{c}\text { Minimum } \\
\text { tillage }\end{array}$ /ha & $\begin{array}{c}\text { Sod } \\
\text { seeding }\end{array}$ & $\begin{array}{c}\text { Traditional } \\
\text { plowing }\end{array}$ \\
Over corn & 5.87 & 6.23 & 6.75 \\
Over alfa alfa & $79.77 \mathrm{~A}$ & 79.90 & $84.43 \mathrm{~B}$ \\
\hline
\end{tabular}

Table 5. Fuel consumption in the trial.

\begin{tabular}{lccc}
$\begin{array}{l}\text { Oil consumption } \\
\mathrm{kg} / \mathrm{ha}\end{array}$ & $\begin{array}{c}\text { Minimum } \\
\text { tillage }\end{array}$ & $\begin{array}{c}\text { Sod } \\
\text { seeding }\end{array}$ & $\begin{array}{c}\text { Traditional } \\
\text { plowing }\end{array}$ \\
Corn & $35.43^{\mathrm{A}}$ & $4.27^{\mathrm{B}}$ & $61.47^{\mathrm{C}}$ \\
Alfalfa & $50.96^{\mathrm{A}}$ & $6.74^{\mathrm{B}}$ & $61.20^{\mathrm{C}}$ \\
\hline
\end{tabular}


Table 6. Energy efficiency and $\mathrm{CO}_{2}$ production.

\begin{tabular}{|c|c|c|c|c|c|c|}
\hline \multirow[t]{2}{*}{ Item } & \multicolumn{2}{|c|}{$\eta=0 u t /$ inp } & \multicolumn{2}{|c|}{ 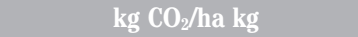 } & \multicolumn{2}{|c|}{$\mathrm{CO}_{2} / \mathrm{kg}$ product } \\
\hline & $\begin{array}{l}\text { At the end } \\
\text { of seeding }\end{array}$ & $\begin{array}{l}\text { Whole crop } \\
\text { cycle }\end{array}$ & $\begin{array}{l}\text { At the end } \\
\text { of seeding }\end{array}$ & $\begin{array}{c}\text { Whole crop } \\
\text { cycle }\end{array}$ & $\begin{array}{l}\text { At the end } \\
\text { of seeding }\end{array}$ & $\begin{array}{c}\text { Whole crop } \\
\text { cycle }\end{array}$ \\
\hline Sod seeding over alfalfa & 21.85 & 8.53 & 349.4 & 895.3 & 0.043 & 0.110 \\
\hline Sod seeding over corn & 17.41 & 5.00 & 335.9 & 1169.8 & 0.054 & 0.187 \\
\hline Plowing over alfalfa & 14.75 & 7.37 & 530.1 & 1075.7 & 0.063 & 0.127 \\
\hline Plowing over corn & 12.22 & 4.70 & 521.1 & 1354.1 & 0.077 & 0.200 \\
\hline Minimum tillage over alfalfa & 15.34 & 7.20 & 487.6 & 1039.5 & 0.061 & 0.130 \\
\hline Minimum tillage over corn & 12.01 & 4.31 & 458.8 & 1280.0 & 0.078 & 0.218 \\
\hline
\end{tabular}

Table 7. Economic evaluation of the trial (prices are referred to OltrePo pavese farms).

\begin{tabular}{|c|c|c|c|c|}
\hline \multirow[t]{2}{*}{ Item } & \multicolumn{2}{|c|}{ Operation } & \multicolumn{2}{|c|}{ Income } \\
\hline & Type & Cost $^{*}(€ / h a)$ & Yield (t/ha) & PLV (€/ha) $(275 € / t)$ \\
\hline \multirow[t]{4}{*}{ Traditional } & Plowing & 180 & & \\
\hline & Soil preparation (rotary tillage) & 105 & 6.78 (over corn) & 1864 \\
\hline & Combined seeding & 120 & & \\
\hline & Total cost of mechanical interventions & 405 & 8.44 (over alfalfa) & 2321 \\
\hline \multirow[t]{3}{*}{ Minimum tillage } & Ripping & 140 & & \\
\hline & Combined seeding & 120 & 5.87 over corn & 1614 \\
\hline & Total cost of mechanical interventions & 260 & 7.97 over alfa alfa & 2192 \\
\hline Sod seeding over corn & Sod seeding & 120 & 6.23 & 1713 \\
\hline \multirow[t]{4}{*}{ Sod seeding over alfalafa } & Preventive weed & 40 & & \\
\hline & Product & 15 & & \\
\hline & Sod seeding & 120 & 8.13 & 2236 \\
\hline & Total & 175 & & \\
\hline
\end{tabular}

appeal; and because of this will most likely spread quickly. According to the authors, however, besides the environmental advantages shown in the Tables, the most interesting feature is the mechanization required. In sod seeding a low-medium horsepower tractor $(75 \mathrm{~kW})$ is employed which can also be used for other operations such as the spreading of agrochemicals. For a cereal farm this means an investment on mechanization of less than $40 \%$ compared to conventional systems.

Anotheer factor of great importance is that this technique can be used in hilly areas where plowing creates soil movement and instability. In addition, conventional cultural practices are extremely expensive if compared to the production attained. The tests carried out during this experiment demonstrated the advantages of sod seeding for autumn vernini cereals in terms of: speed, minimal use of manpower, reduced investment and operation costs, limited erosion and instability. Factors which can relaunch the agro-animal husbandry sectors in the alpine and appenine areas; consequently keeping and protecting the territory and its environment.

\section{References}

Bonari, E., Mazzoncini, M., Peruzzi, A. and Silvestri, N., 1992. Valutazioni energetiche di sistemi produttivi a divers.0 livello di intensificazione coltmale. Inform. Agrar. Suppl., 1: 1-25.

Borin M., Menini C., Sartori L. 1997. Effects of tillage systems on ener- gy and carbon balance in north-eastern Italy. Soil \& Tillage Research 40 (1997) 209-226.

Cantele, A. and Zanin, G., 1983. Diserbanti ed energia: considerazioni sul loro impiego in agricoltura. Riv. Agron., 17: 65-17.

Cavalchini A.G. 1977. Valutazione delle diverse tecniche di raccolta e conservazione dei foraggi prativi in funzione del rendimento energetico. Rivista di Ingegneria Agraria. $\mathrm{N}^{\circ}$ 5-4.

Derpsch R, Friedrich T., Kassam A., Houghven L. 2010. Current status of adoption of no-till farming in the world and some of its major benefits. Int. J. Agric. \& Biol. Eng. 3,1: 1-26.

Manby T. 1975. Energy use in Agriculture. The agricultural Engineer. $\mathrm{N}^{\circ} 3$. Ribera L. A., Honsb F. M., Richardsona J.M, James W. 2004. An Economic Comparison between Conventional and No-Tillage Farming Systems in Burleson County, Texas Agronomy Journal 96,2:415-424.

Sartori, L. and Peruzzi, A., 1994. The evolution of no-tillage in Italy: a review of the scientific literature. Proc. 1st EC Workshop on Experience with the Applicability of No-tillage Crop Production in the West.

Terbrigge, F., Grol3, U., Bohmsen, A. and During, R.A., 1994. Advantages and Disadvantages of Conservation- and No-Tillage Compared to Plough Tillage. Proc. hit. Agric. Eng. Conf., Bangkok, 6-9 December 1994.

Toderi, G. and Bonari, E., 1986. Lavorazioni de1 terreno: aspetti agronomici. I. Interazioni tra lavorazioni e terreno, clima, altre tecniche agronomiche. Riv. Agron., 2@2-3): 85-105. 